\title{
The Trend in Using Online Meeting Applications for Learning During the Period of Pandemic COVID-19: A Literature Review
}

\section{Hendri Pratama ${ }^{1 *}$, Mohamed Nor Azhari Azman', Gulzhaina K. Kassymova ${ }^{2,3}$, Shakizat S. Duisenbayeva $^{4}$}

\author{
${ }^{1}$ Sultan Idris Education University, Malaysia \\ ${ }^{2}$ Abai Kazakh National Pedagogical University, Republic of Kazakhstan \\ ${ }^{3}$ Institute of Metallurgy and Ore Beneficiation, Satbayev University, Republic of Kazakhstan \\ ${ }^{4}$ Al-Farabi Kazakh National University, Republic of Kazakhstan \\ *Correspondence to: hendripratama.tvet@gmail.com
}

\begin{abstract}
The pandemic COVID-19 has given a very significant impact on the lives of the world community, especially in the field of education. The existence of remote learning is an alternative for the community to reduce the impact of outbreaks. This alternative changes the direction of physical learning into online and virtual learning. The use of online meeting applications is an option that provides many conveniences for students and teachers to achieve learning goals without being in class. Various types of applications can be used by the needs and interests of the people. This study is carried out to examine the trend in using online meeting applications to learn during the outbreak period. This study was conducted using qualitative methods through descriptive analysis of the results of observations and documentation. This scenario shows the increment of the usage of these applications in the teaching and learning process (P\&P). The use of this application is very helpful in the teaching and learning process between teachers and students. Overall, there is an increasing trend and give the effect towards usage of online meeting applications in solving learning problems in the future.
\end{abstract}

Keywords: Trends; Online Meeting Application; COVID-19

Recommended citation: Pratama, H., Azman, M. N. A., Kassymova, G. K., \& Duisenbayeva, S. S. (2020). The Trend in Using Online Meeting Applications for Learning During the Period of Pandemic COVID-19: A Literature Review. Journal of Innovation in Educational and Cultural Research, $1(2), 58-68$

\section{INTRODUCTION}

Since it has been discovered in Wuhan city, the COVID-19 is rapidly spread globally, which caused the pandemic. On $30^{\text {th }}$ January 2020, the World Health Organization (WHO) declared it as an emergency state of health to the public that disturbs the world (Dewi, 2020). COVID-19 is one of the most dangerous viruses because it attacks the respiratory system, with symptoms of fever, coughing, and colds. The average incubation period for this virus is five to six days, with the most extended incubation period reaching 14 days (Dewi, 2020).

The existence of COVID-19 has a significant impact on the world community. The impact of the virus can be felt in many fields, such as social, economic, tourism, and education. The field of education, in particular, the existence of COVID-19, caused many countries to close schools from the lowest levels until the university level. The closure of school has a significant impact on protecting more than 570 million students in the world (UNESCO, 2020). However, UNESCO, which is also supported by UNICEF, WHO, and IFRS, suggested that the learning process would continue through online learning (Afriansyah, 2020). The implementation of social distancing by the government causes the online meeting application to be an initiative for all levels of society, such as business people, the government, the public, and students, to remain prominent and communicate virtually.

Since COVID-19 has been recognised as a plague at the international level, public places, companies, and schools have to be closed so that all learning activities have to be carried out at home and transformed into online meetings and classes that can be accessed online. It makes many online meeting or video conference applications vital because almost all of the world population uses them. 
Online learning opens up new solutions in the education world through the innovation of technology. Online learning must be supported by supporting devices such as software and hardware. Oranburg (2020) classifies two tools that allow teachers and students to be connected in the implementation of online learning. The hardware equipment includes computers in CPUs, laptops, webcams, microphones, and internet networks. From the software, the teachers and students also need to have special knowledge to use online learning support applications such as the use of teleconferences or video call applications, such as WhatsApp, Zoom, and others. Video conference is a technology that allows users in different locations to hold prominent meetings without having to move or meet at the same location. This technology is felt comfortable and practical when learning is done directly (live). It certainly can save time without having difficulties related to travel so that it can complete the work but still be safe in their homes - even though there is a plague.

Indeed, teachers and students should take the opportunity to use technology to improve the quality of learning. There is research evidence that digital technology creates an environment to develop human cognition and digital competence (Kassymova et al., 2019a, 2019b; Kassymova et al., 2020). Teachers and students need to adapt to the ways and processes of life skills education in the future by utilizing the role of technology to support education; they also need to develop their competencies in teaching (Kassymova, 2018; Aksarina et al., 2019; Triyono et al., 2020).

Various media can be used to support online learning, for example, online learning using Google Classroom, Emodo, Schoology, Zoom, and many more (Enriquez, 2014; Sicat, 2015; Iftakhar, 2016), and instant messaging applications such as WhatsApp (So, 2016 ). In distance learning, the use of technology makes an immense contribution to educational institutions. This study was conducted to identify the platforms that are often used in virtual classes during online learning and obtain an overview of the factors that influence the choice of these platforms during the implementation of distance learning.

\section{METHODS}

This study is a literature review. The method used is to collect and review journals about the usage of online meeting applications that are in the scope of the same discussion with the problems encountered. Sources of data in this research were obtained from news, articles, and journal publications. News, articles, and journals used as review materials are selected based on two criteria, good publication and reputation as a trusted publication media. It means that in this research, the source reviewed is a publication media that is suitable for study.

\section{Participants}

Participants are subjects who are involved both mentally and emotionally as participants in responding to activities carried out in the teaching and learning process and supporting the achievement of goals and are responsible for their involvement. Participants in this study were educators, both teachers, and lecturers, as well as students who used the online meeting learning platform. The number of participants was 52 people consisting of 19 teachers, ten lecturers, and 23 students. The total participants consist of 23 men and 29 women.

\section{Instrument}

The instruments used in this study were in the form of observation and documentation. Besides, interviews were also conducted with representatives of educators and students to find out an overview of the implementation of online learning, the platform used, the obstacles faced, and the factors affecting the choice of platform. Observation is in the form of aspects checklist of implementation and problems in online learning. The observation sheet is also equipped with observer notes in the form of a description of the observation findings. The open interview instrument was given to all participants online using the WhatsApp group. The instrument for collecting data from documents about online learning is to verify the results of observations and interviews. 


\section{Data Collection}

The data collection technique of the study is carried out by documentation, to recognize the variables or subjects studied through notes, books, papers, and news articles to journal publications (Arikunto, 2010). The data collected using the observation instrument was obtained from instruments filled in by the observer. Interview data from telephone calls and WhatsApp groups were collected in the form of a description of the interview results.

\section{Data Analysis}

The data that has been collected is then analyzed using content analysis, which is an in-depth discussion of information that has been listed in the literature. The content analysis technique is done by making the contents available in the literature as objects and also obtaining inferences that can be imitated and valid, and can be examined in more detail by the established context. The content analysis procedure is carried out in this study aims to provide facts on the phenomenon under study, which is the trend of using online meeting applications for remote learning during the COVID-19 character through several journals.

\section{RESULTS AND DISCUSSION}

Studies related to remote learning using the online meeting application will be described in the form of a table based on the results of the content analysis conducted on several journals and articles that are suitable for the objectives of the research. Naciri et al. (2020) stated that the role of remote learning as alternative learning that could not be avoided during COVID-19. It was because learning could be done from long distance. The use of this system allows learning at any time and anywhere. Remote learning is an alternative that cannot be avoided during COVID-19. However, the use of online media during the COVID-19 pandemic caused various responses on the impact and changes in learning systems that can affect the teaching and learning process (P\&P) and the level of student development in responding to the material presented (Jaelani et al., 2020).

A study by Naserly (2020) stated that Zoom is an effective platform to be used with students for less than 20. If more than that, then the Zoom activity must be divided into two or three sessions to maintain the effectiveness of online learning. Besides, Zoom is a live streaming application with quotaredundant characters, the duration of the live streaming can be shortened for 10-15 minutes per meeting so that interactions between teachers and students remain as intertwined as conventional classroom learning. Furthermore, the delivery of additional material and the collection of tasks can be done through Google Classroom and monitored in real-time and intensely through the WhatsApp group. Along with the study of Brahma (2020) suggested that the use of Zoom makes it easier to collect qualitative data because it is cost-effective, and the security is maintained.

Differs from the study of Permata \& Bhakti (2020) suggested that the use of Google Classroom is less memorable in physical learning, but it is effective in learning through virtual classes and can be used as learning applications during the COVID-19 pandemic. It can be concluded that students still need teachers directly in the physical learning process. In learning, the usage of Google Classroom gives an impact of a practical mathematical reasoning ability for students (Santosa et al., 2020). Also, through this application, student discipline attitudes can be trained. However, it is necessary to improve learning with support applications that can facilitate teachers and students to stand out directly through the network (web) as in the use of Google Meet.

Along with the study of Idad et al. (2020), using the Google Classroom application in learning during the COVID-19 period was excellent and effective, and it would be better if combined with other online platforms. It can be seen from the high number of students who have a high motivation to learn in online learning (Umairah \& Zulfah, 2020). 
In the clinical and anatomical fields, Google Hangouts can compensate for the loss of daily lessons from the surgical department through the video conference (Moszkowicz et al., 2020). These results mean using applications to be the right solution in solving learning problems during the pandemic COVID-19. It is in line with the study of Rusdiana et al. (2020) that learning problems can be overcome by developing models such as Blended Learning by using Google Classroom. Meanwhile, Mastoni \& Rahmawati (2019) found that the use of the Google Classroom application can help to facilitate the scholars and students in carrying out the learning process in-depth. It is because both students and lecturers can collect assignments, assign assignments, and assess assignments at home or anywhere without being bound by time or learning time.

Technological developments have resulted in many applications popping up and can be used through portable devices, including Zoom, Google Meet, WhatsApp, Facebook, and others. However, among all these applications, WhatsApp is the most popular and easy application for sending photos, audio, documents, and videos not only for the individual but can also be done in groups with various facilities available on WhatsApp, so it is appropriate for educators and students to use WhatsApp as one of the learning media, especially during the COVID-19 period.

The results obtained the previous research related to the usage of online applications for learning during the COVID-19 period can be seen in Table 1.

Table 1. Research on the usage of online meeting applications for learning during the period of COVID19.

\begin{tabular}{|c|c|c|}
\hline $\begin{array}{l}\text { Name of } \\
\text { Researchers } \\
\text { (Year) }\end{array}$ & Research Title & Contribution \\
\hline $\begin{array}{l}\text { Naciri et al } \\
\text { (2020) }\end{array}$ & $\begin{array}{l}\text { Mobile Learning di Pengajian } \\
\text { Tinggi: Alternatif yang Tidak } \\
\text { Boleh Dihindari semasa COVID- } \\
19\end{array}$ & $\begin{array}{l}\text { This study reflects the role of remote learning as a strategy } \\
\text { of long-distance learning that supports student-centered } \\
\text { learning. The use of mobile learning allows learning at any } \\
\text { time and anywhere. Mobile learning is an inevitable } \\
\text { alternative during COVID-19. }\end{array}$ \\
\hline $\begin{array}{l}\text { Jaelani et al } \\
\qquad(2020)\end{array}$ & $\begin{array}{l}\text { Penggunaan Media Online } \\
\text { Dalam Proses Kegiatan Belajar } \\
\text { Mengajar Pai Dimasa Pandemi } \\
\text { COVID-19 (Studi Pustaka dan } \\
\text { Observasi Online) }\end{array}$ & $\begin{array}{l}\text { The use of online media during the pandemic of COVID-19 } \\
\text { led to various responses towards the impact and changes in } \\
\text { learning systems that can affect the teaching and learning } \\
\text { process (P\&P) and the level of student development in } \\
\text { responding to the material presented. }\end{array}$ \\
\hline $\begin{array}{l}\text { Naserly } \\
(2020)\end{array}$ & $\begin{array}{l}\text { Penerapan Zoom, Google } \\
\text { Classroom, Dan WhatsApp } \\
\text { Group Dalam Mendukung } \\
\text { Pembelajaran Daring (Online) } \\
\text { Pada Mata Kuliah Bahasa Inggris } \\
\text { Lanjut. }\end{array}$ & $\begin{array}{l}\text { Zoom is a suitable and sufficient platform to be used for } \\
\text { less than } 20 \text { students. If more than that, then the Zoom } \\
\text { activity must be divided into two or three sessions to } \\
\text { maintain its effectiveness. Furthermore, Zoom is a live } \\
\text { streaming application with quota-redundant characters, the } \\
\text { duration of the live streaming can be shortened for ten until } \\
15 \text { minutes per meeting so that interactions between } \\
\text { teachers and students remain as intertwined as } \\
\text { conventional classroom learning. Thud, the delivery of } \\
\text { additional material and the collection of tasks can be done } \\
\text { through Google Classroom and monitored in real-time and } \\
\text { intensely through the WhatsApp group. }\end{array}$ \\
\hline Brahma & $\begin{array}{l}\text { Penggunaan Zoom Sebagai } \\
\text { Pembelajaran Berbasis Online } \\
\text { Dalam Mata Kuliah Sosiologi dan }\end{array}$ & $\begin{array}{l}\text { The use of Zoom makes it easier to collect qualitative data } \\
\text { because it is more cost-effective and security is maintained. }\end{array}$ \\
\hline
\end{tabular}




\begin{tabular}{|c|c|c|}
\hline$(2020)$ & $\begin{array}{l}\text { Antropologi Pada Mahasiswa } \\
\text { PPKN }\end{array}$ & \\
\hline $\begin{array}{l}\text { Permata \& } \\
\text { Bhakti } \\
\text { (2020) }\end{array}$ & $\begin{array}{l}\text { Keberkesanan Virtual Class } \\
\text { dengan Google Classroom dalam } \\
\text { Pembelajaran Fizik dimasa } \\
\text { Pandemic Covid - } 19\end{array}$ & $\begin{array}{l}\text { Google Classroom is less effective in physical learning, but } \\
\text { has been effective through virtual classrooms and can be } \\
\text { used as learning applications in the pandemic Covid- } 19 \text {. So } \\
\text { it can be concluded that students still need teachers directly } \\
\text { in the physical learning process. }\end{array}$ \\
\hline $\begin{array}{c}\text { Santosa et al } \\
\text { (2020) }\end{array}$ & $\begin{array}{l}\text { Keberkesanan Pembelajaran } \\
\text { Google Classroom Terhadap } \\
\text { Kemampuan Penalaran } \\
\text { Matematis Pelajar }\end{array}$ & $\begin{array}{l}\text { Learning through Google Classroom for practical student } \\
\text { mathematical reasoning abilities. The discipline of students } \\
\text { can be trained through Google Classroom. Another finding } \\
\text { is that improving the application of Google Classroom in } \\
\text { learning is needed for supporting applications that can } \\
\text { facilitate teachers and students to meet face to face via the } \\
\text { network (web) such as the use of Google Meet. }\end{array}$ \\
\hline $\begin{array}{l}\text { Idad et al } \\
\text { (2020) }\end{array}$ & $\begin{array}{l}\text { Pembelajaran dalam talian } \\
\text { berasaskan Google Classroom } \\
\text { mahapelajar pendidikan biologi } \\
\text { pada masa wabah Covid - } 19 \\
\end{array}$ & $\begin{array}{l}\text { The use of the Google Classroom application in learning } \\
\text { online during the Covid-19 period is excellent and effective. } \\
\text { It would be better if combined with other online platforms. }\end{array}$ \\
\hline $\begin{array}{l}\text { Umairah \& } \\
\text { Zulfah } \\
\text { (2020) }\end{array}$ & $\begin{array}{l}\text { Peningkatan Motivasi Belajar } \\
\text { Menggunakan Google Classroom } \\
\text { Ditengah Pandemi COVID - } 19\end{array}$ & $\begin{array}{l}\text { The total of students who have high learning motivation is } \\
17 \text { students, and one student has mathematics learning } \\
\text { motivation while learning through Google Classroom. }\end{array}$ \\
\hline $\begin{array}{c}\text { Moszkowicz et } \\
\text { al } \\
(2020)\end{array}$ & $\begin{array}{l}\text { Pendidikan perubatan harian } \\
\text { untuk pelajar yang terkurung } \\
\text { semasa pandemik COVID - 19: } \\
\text { Persidangan video yang ringkas } \\
\text { penyelesaian }\end{array}$ & $\begin{array}{l}\text { The easy and free teaching method aims to compensate for } \\
\text { the loss of daily lessons conducted in surgery department } \\
\text { by using the Google Hangouts application. The video } \\
\text { conference method may be used for clinical and anatomical } \\
\text { studies. }\end{array}$ \\
\hline $\begin{array}{c}\text { Rusdiana et al } \\
\text { (2020) }\end{array}$ & $\begin{array}{l}\text { Penerapan Model POE2WE } \\
\text { Berbasis Blended Learning } \\
\text { Google Classroom Pada } \\
\text { Pembelajaran Masa WFH } \\
\text { Pandemic COVID - } 19 \\
\end{array}$ & $\begin{array}{l}\text { The implementation of the POE2WE model based on } \\
\text { Blended Learning through Google Classroom media can be } \\
\text { used as a solution to the problem in the WFH Pandemic } \\
\text { COVID-19 Learning Process. }\end{array}$ \\
\hline $\begin{array}{c}\text { Mastoni \& } \\
\text { Rahmawati } \\
\text { (2019) }\end{array}$ & $\begin{array}{l}\text { Desain Pembelajaran Bahasa } \\
\text { Inggris Melalui Google } \\
\text { Classroom }\end{array}$ & $\begin{array}{l}\text { This application can help and facilitate scholars and } \\
\text { students in carrying out the learning process in-depth. It is } \\
\text { because both students and lecturers can collect } \\
\text { assignments, assign assignments, and assess assignments } \\
\text { at home or anywhere without being bound by time or study } \\
\text { time. }\end{array}$ \\
\hline $\begin{array}{c}\text { Napratilora et } \\
\text { al } \\
(2020)\end{array}$ & $\begin{array}{l}\text { Using WhatsApp as a Learning } \\
\text { Media in Teaching Reading }\end{array}$ & $\begin{array}{l}\text { The technology that continues to develop made the } \\
\text { emergence of applications that can be used with } \\
\text { smartphones, such as Zoom, Google Meet, WhatsApp, } \\
\text { Facebook, and others. Among all these applications, } \\
\text { WhatsApp is the most popular and easy to use application. } \\
\text { Through WhatsApp, we can send photos, audio, } \\
\text { documents, and videos not only individually. However, we } \\
\text { can also be done in groups with various facilities available } \\
\text { in the WhatsApp feature, so it is appropriate for educators } \\
\text { and students to use WhatsApp as the learning platform in } \\
\text { the COVID-19 period. }\end{array}$ \\
\hline
\end{tabular}

Most of the studies show the positive impact of using online meeting applications in learning during the COVID-19 period. However, for other results, there are some weaknesses and technical 
obstacles to using these applications. However, these obstacles and weaknesses can be overcome by getting used to selecting applications that suit their individual needs. It implies that developing a learning management system based on online meeting applications requires continuous improvement to provide better quality education (Azman et al., 2020).

In supporting the success of the learning and teaching process, teachers and students are undoubtedly familiar with various learning media such as audio-visual media and information technology. Changes in conditions caused by Covid-19 affect behavior and learning methods during social distancing. Students are not allowed to follow regular learning as usual in school to avoid or suppress the spread of Covid-19. So that education can still be done, the government recommends educators or students to carry out teaching and learning activities online by utilizing technology.

The implementation of social distancing to prevent the spread of Covid-19 encourages the use of information media and telecommunications for work and online learning. Working and learning from home can be done using various types of platforms available so that activities can be carried out well. Online learning can be done in the form of video conferencing. Some of the platform options used were quite effective during the social distancing period. One of them is the Zoom technology that allows all participants to see and hear each classmate and discuss using any device, including a tablet, iPhone, and computer. Sharma (2020) mentioned that the Zoom application is still doubtful of its security level in some countries; even Google prohibits its employees from using the Zoom application to conduct online meetings. However, based on data from the Google Play Store application, the Zoom Meetings application has been download with a double amount of users compared to the Google Meet application with a total load drop of more than 100 million users. A comparison of drop-down numbers between the Zoom and Google Meet can be seen in Figure 1. Figure 1 shows a prominent display of various online meeting applications that were commonly used during the Covid-19 period.

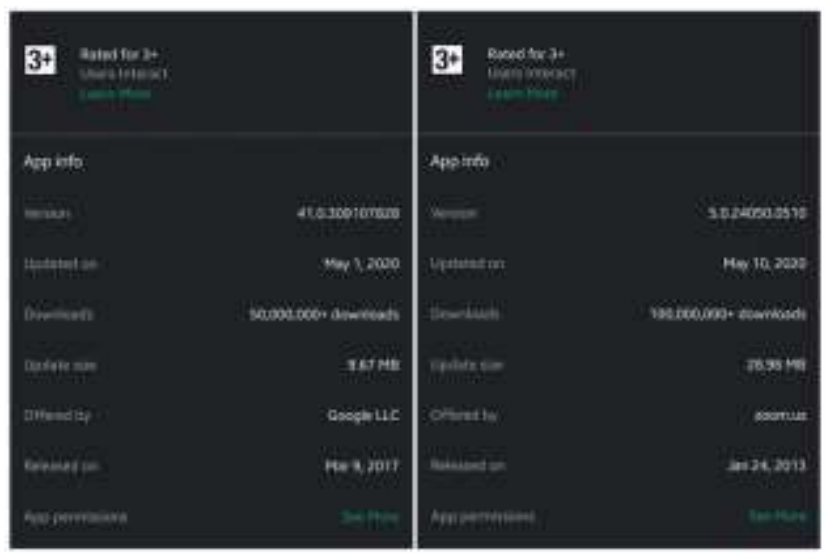

Figure 1. The number of users downloads for Google Meet (left) and Zoom Meetings (right) (Source: kompas.com, 2020) 

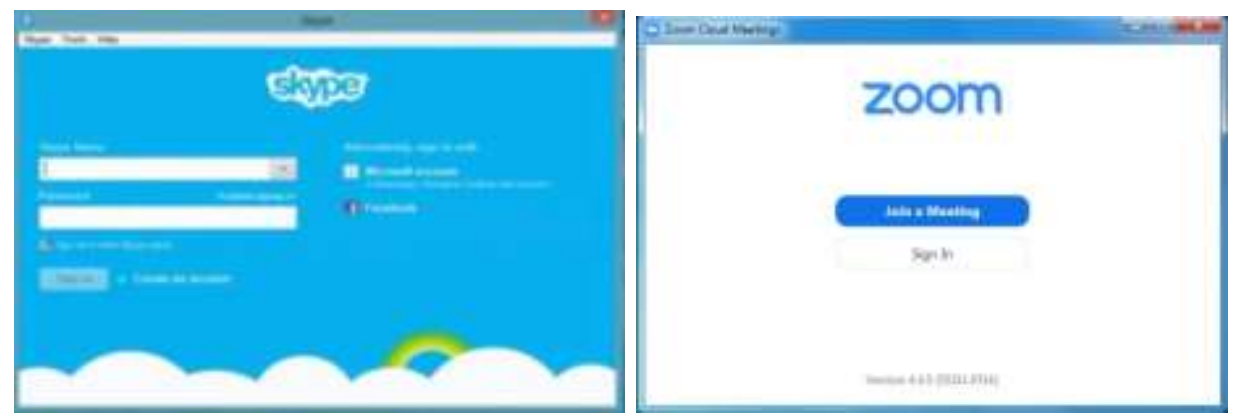

(a). The first display of the Zoom Meeting application; (b). The first display of the Skype application
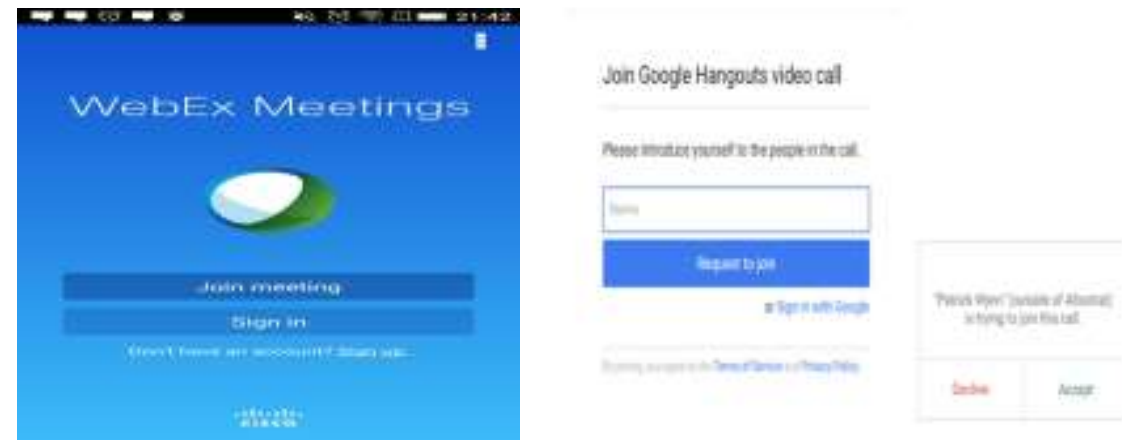

(c). The first display of the Webex Meetings application; (d). The first display of Google Hangout

Figure 2. Various display options for online meeting platforms

Referring to data from Statqo Analytics, the use of online applications is increasing every week. Meanwhile, the number of Zoom applications has increased significantly, reaching 183 percent starting from $6^{\text {th }}$ to $26^{\text {th }}$ March 2020. On 26th March, the Zoom application recorded 257,853 users, wherein 19th March, the user reached 91,030 users.

On the other hand, Skype application users recorded 71,155 users, which is an increase of 8.02 percent increment than the previous usage, which reached 65,875 people. When the Hangout Meet application experienced a significant increase in traffic through community use, it was recorded that on 19th March 2020, it reached 7.917 percent, which increased on $26^{\text {th }}$ March by 10.454 percent, with an increase of 32.14 percent.

Meanwhile, Cisco Webex Meeting users confirmed a 5.95 percent increase in the number of users by 8,748 users on $26^{\text {th }}$ March, which previously recorded 8,257 users. The GoToMeeting application on $26^{\text {th }}$ March successfully reached 977 users after a week before 696 users accessed it. So that this application has recorded a relatively high increment of 40.37 percent. For more clearly, the number of percent of video conference applications can be seen in Table 2.

Table 2. Active users of online meeting applications (in number of users)

\begin{tabular}{lrrrr}
\hline \multirow{2}{*}{ Type of application } & \multicolumn{4}{c}{ Period of usage } \\
\cline { 2 - 5 } & 28 Feb - 5 March & $6-12$ March & 13 - 19 March & 20 - 26 March \\
\hline Zoom & 8.714 & 8.985 & 91.030 & 257.853 \\
Skype & 60.614 & 60.641 & 65.875 & 17.115 \\
Hangout Meet & 1.448 & 1.554 & 7.917 & 10.454 \\
Cisco Web Meeting & 3.983 & 4.123 & 8.257 & 8.748 \\
GoToMeeting & 479 & 505 & 696 & 977 \\
\hline \multicolumn{4}{c}{}
\end{tabular}


On the other hand, the use of online meeting applications is also influenced by the ability of individuals in the selection of online meeting applications. The selection can be in the form of user friendly, the purpose or interest of using the application, consideration of the advantages and disadvantages of the application, and also the reasons for the need for more internet quota usage. Hutchison et al. (2016) reviewed four popular teleconferencing applications, i.e., Hangouts, Zoom, Skype, and Webex, to identify which the most is saving the internet data. The smooth functioning of the video conference application depends on sufficient bandwidth so that the conversation can take place smoothly without any disturbance. The study was conducted using the same tool for a 30-minute conference with a total of 8 participants. The results of the study found that the Zoom application was the most saving for a bandwidth requirement of around $700 \mathrm{kbps}$. Then it is followed by Skype, Hangouts, and Webex applications (McHugs et al., 2012). The need for bandwidth usage can be seen in Figure 3.

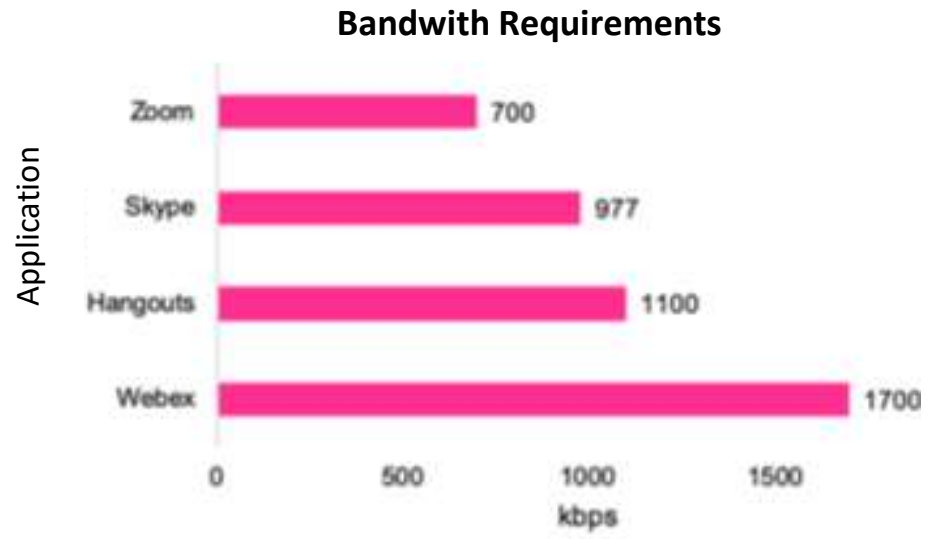

Figure 3. Bandwidth requirements in online meeting application

(Source: McHugs et al., 2012)

\section{CONCLUSION}

The phenomenon of the Covid-19 virus outbreak caused a fundamental change in the field of education. The first change is to change the educational process, then open up new solutions for education through technological innovation, and show the occurrence of digital disparities that cause the implementation of technological innovation in education. Learning can be done through this technological innovation is learning with virtual classrooms (Amirrachman, 2020). All the online meeting applications discussed can be concluded that this application provides and brings tangible benefits because the video conference is proven to be more efficient, practical, and safe. Communication exchanges and a sense of community are also maintained, although they can only be seen in visual and audio form. For the use of work, online learning classes and video conferences can overcome the distance factor so that anyone in any part of the world can share information, especially sharing news announcements about the spread of Covid-19. This interactive technology is proven effective in all levels and aspects of life, and even each user is no longer limited to visual or audio appearance. It also can send files and interact like conventional meetings such as writing the contents of meetings on a digital whiteboard. It certainly changes the paradigm in education that the learning process or activity should not always have to be carried out in the class. Therefore, the use of applications is not only done when there is a disaster, but also as a new learning style in achieving learning objectives in the future. 


\section{REFERENCES}

Afriansyah, A. (2020). Covid - 19, Transformasi Pendidikan dan Berbagai Problemnya. Accessed https://kependudukan.lipi.go.id/id/berita/53-mencatatcovid19/838-Covid-19-transformasipendidikandan-berbagai-problemnya pada 20 Juli 2020.

Aksarina, I. Y., Dossayeva, S. K., Kosov, A. V., Stepanova, G. A., \& Kassymova, G. K. (2019). Foresight innovations in educational systems in the BRICS countries. Bulletin of National academy of sciences of the Republic of Kazakhstan, 4(380), 123-131.

Amirrachman, A. (2020). Covid-19 Ubah Lanskap Pendidikan, Munculkan Trend Baru. Accessed https://ibtimes.id/covid19-ubah-lanskap-pendidikan-munculkantrend-baru/.

Arikunto, S. (2010). Prosedur Penelitian: Suatu Pendekatan Praktek. Jakarta: Rineka Cipta.

Azman, M. N. A., Kamis, A., Che Kob, C. G., Abdullah, A. S., Jerussalem, M. A., Komariah, K., \& Budiastuti, E. (2020). How Good Is My Guru: The Lecturers' Percieved Usefullness and Attitude. Cakrawala Pendidikan. $39(2), 422-431$,

Brahma, I. A. (2020). Penggunaan Zoom Sebagai Pembelajaran Berbasis Online Dalam Mata Kuliah Sosiologi dan Antropologi Pada Mahapelajar PPKN di STKIP Kusumanegara Jakarta. Jurnal Ilmu Pendidikan Nonformal. 6(2), 97-102.

Dewi, W. A. F. (2020). Dampak COVID - 19 terhadap Implementasi Pembelajaran Daring di Sekolah Dasar. Edukatif: Jurnal Ilmu Pendidikan, 2(1), 55-61.

Enriquez, M. A. S. (2014, March). Students' Perceptions on the Effectiveness of the Use of Edmodo as a Supplementary Tool for Learning. In DLSU Research Congress (pp. 1-6).

Hutchison, B. J., Gal, O., Verwayen, P., \& Periyannan, A. (2016). U.S. Patent No. 9,369,673. Washington, DC: U.S. Patent and Trademark Office.

Iftakhar, S. (2016). Google classroom: what works and how. Journal of Education and Social Sciences, 3(1), 1218.

Jaelani, A., Fauzi, H., Aisah., \& Zaqiyah, Q. Y. (2020). Penggunaan media online dalam proses kegiatan belajar mengajar pai dimasa pandemi COVID-19. Jurnal Ikatan Alumni PGSD UNARS. 8(1), 12-24.

Kassymova, G. K. (2019). Duisenbayeva Sh. S., Adilbayeva UB, Khalenova AR, Kosherbayeva AN, Triyono MB, Sangilbayev OS Cognitive Competence Based on the E-Learning. International Journal of Advanced Science and Technology, 28(18), 167-177.

Kassymova, G., Arpentieva, M., Kosherbayeva, A., Triyono, M., \& Sangilbayev, O. (2019b). Science, education \& cognitive competence based on e-learning. Bulletin of National academy of sciences of the Republic of Kazakhstan, 1(377), 269-278.

Kassymova, G., Bekalaeva, A., Yershimanova, D., Flindt, N., Gadirova, T., \& Duisenbayeva, S. H. (2020). ELearning Environments and Their Connection to the Human Brain. International Journal of Advanced Science and Technology, 29(9s), 947-954.

Kassymova, G. (2018). Competence and its implications. Challenges of Science. https://doi.org/10.31643 12018.063 
Kompas.com. (2020). Hangouts, Zoom, Skype, dan Webex, Mana yang Paling Jimat Data?, https://tekno.kompas.com/read/2020/04/01/12010057/hangouts-Zoom-skype-dan-webex-mana-yangpaling-irit-data.

Kompas.com. (2020). Kompas.com dengan judul "Layanan "Meeting Online" Google Meet Tembus 50 Juta Unduhan", https:/tekno.kompas.com/read/2020/05/19/15180007/layanan-meeting-online-google-meettembus-50-juta-unduhan?page=all.

Mastoni, M., \& Rahmawati, R. (2019, March). Desain Pembelajaran Bahasa Inggris Melalui Google Classroom. In Prosiding Seminar Nasional Program Pascasarjana Universitas Pgri Palembang (Vol. 12, No. 01).

McHugs, J. E., Wherton, J. P., Prendergast, D. K., \& Lawlor, B. A. (2012). Teleconferencing as a source of social support for older spousal caregivers: initial explorations and recommendations for future research. American Journal of Alzheimer's Disease \& Other Dementias ${ }^{\circledR}, 27(6), 381-387$.

Moszkowicz, D., Duboc, H., Dubertret, C., Roux, D., \& Bretagnol, F. (2020). Daily medical education for confined students during COVID-19 pandemic: A simple videoconference solution. Clinical Anatomy. 33(5),

Naciri, A., Baba, M. A., Achbani, A., \& Kharbach, A. (2020). Mobile learning in Higher education: Unavoidable alternative during COVID-19. Aquademia, 4(1), ep20016.

Napratilora, M., Lisa H., \& Bangsawan, I. (2020). Using WhatsApp as a Learning Media in Teaching Reading. MITRA PGMI: Jurnal Kependidikan MI, 6(2), 116-125.

Naserly, M. K. (2020). Penerapan Zoom, Google Classroom, Dan Whatsapp Group Dalam Mendukung Pembelajaran Daring (Online) Pada Mata Kuliah Bahasa Inggris Lanjut (Studi Kasus Pada 2 Kelas Semester 2, Jurusan Administrasi Bisnis, Fakultas Ekonomi dan Bisnis, Universitas Bina Sarana Informatika Jakarta). Aksara Public, 4(2), 155-165.

Oranburg, S. (2020). Distance Education in the Time of Coronavirus: Quick and Easy Strategies for Professors. Legal Studies Research Paper Series. Duquesne University School of Law Research Paper, 2020-02.

Permata, A., \& Bhakti, Y. B. (2020). Keefektifan Virtual Class dengan Google Classroom dalam Pembelajaran Fisika Dimasa Pandemi Covid-19. JIPFRI (Jurnal Inovasi Pendidikan Fisika Dan Riset Ilmiah), 4(1), 27-33.

Rusdiana, A., Sulhan, M., Arifin, I., \& Kamludin, U. (2020). Penerapan Model POE2WE Berbasis Blended Learning Google Classroom Pada Pembelajaran Masa WFH Pandemic Covid-19. Karya Tulis IImiah UIN Bandung, p.1-10.

Santosa, F. H., Negara, H. R. P., \& Bahri, S. (2020). Efektivitas pembelajaran google classroom terhadap kemampuan penalaran matematis siswa. Jurnal Pemikiran Dan Penelitian Pendidikan Matematika (JP3M), 3(1), 62-70.

Sharma, A. (2020). Is Zoom safe? Yet another country doesn't seem to think so. Accessed https://www.androidauthority.com/Zoom-india-unsafe-advisory-1108248/15 July 2020.

Sicat, A. S. (2015). Enhancing college students' proficiency in business writing via schoology. International Journal of Education and Research, 3(1), 159-178.

Triyono, B. M., Mohib, N., Kassymova, G. K., Pratama, G. N. I. P., Adinda, D., \& Arpentieva, M. R. (2020). The Profile Improvement of Vocational School Teachers' Competencies. Vysshee obrazovanie $v$ Rossii= Higher Education in Russia, 29(2), 151-158.

Umairah, P., \& Zulfah, Z. (2020). Peningkatan Motivasi Belajar Menggunakan Google Classroom Ditengah Pandemi Covid-19 Pada Peserta Didik Kelas XI IPS 4 SMAN 1 Bangkinang Kota. Journal on Education, 2(3), 275-285. 
United Nations of Educational. (2020). COVID - 19 And Higher Education: Today and Tomorrow. Accessed http://www.iesalc.unesco.org/en/wpcontent/uploads/2020/04/COVID - 19-EN-090420-2.pdf. 